\title{
Evaluating Trade Corridor Performance: A Myanmar Case Study
}

Author(s): Ruth Banomyong, Thomas E. Fernandez

Source: Journal of International Logistics and Trade 2021; 19(1):19-32

Published by: Jungseok Research Institute of International Logistics and Trade, Inha University

DOI: https://doi.org/10.24006/jilt. 2021.19.1.019

Journal of International Logistics and Trade is an official journal published by Jungseok Research Institute of International Logistics and Trade, Inha University, Korea. JILT welcomes manuscripts that advance the practice and science of logistics, trade, and other related fields.

Frequency: Quarterly (March, June, September, December)

Stable URL: https://www.ejilt.org

Jungseok Research Institute of International Logistics and Trade is a specialized academic research institute representing Inha University and Inha Foundation in Korea. The institute aims to become a representative institute in Northeast Asia in the research of logistics and trade.

Stable URL: https://jrieng.inha.ac.kr

(C) Copyright. Jungseok Research Institute of International Logistics and Trade.

This is an Open-Access article distributed under the terms of the Creative Commons Attribution NonCommercial License (http://creativecommons.org/licenses/by-nc/4.0/) which permits unrestricted noncommercial use, distribution, and reproduction in any medium, provided the original work is properly cited 


\title{
Journal of International Logistics and Trade
}

J. Int. Logist. Trade, 2021, Vol. 19, No. 1, 19-32

pISSN : 1738-2122 eISSN : 2508-7592

https://doi.org/10.24006/jilt.2021.19.1.019

https://www.ejilt.org

\section{ARTICLE}

\section{Evaluating Trade Corridor Performance: A Myanmar Case Study}

\author{
Ruth Banomyong ${ }^{1}$, Thomas E. Fernandez ${ }^{2, *}$ \\ ${ }^{1}$ Thammasat University, Bangkok 10200, Thailand \\ ${ }^{2}$ University of the Thai Chamber of Commerce, Bangkok 10400, Thailand
}

Received September 06, 2020
Revised December 17, 2020
Accepted March 29, 2021

*Corresponding author: Thomas E.
Fernandez
University of the Thai Chamber of
Commerce, Bangkok 10400, Thailand
Tel: +66-81-833-0416
E-mail: thomas.utcc@gmx.net

Received September 06, 2020

Revised December 17, 2020

Accepted March 29, 2021
*Corresponding author: Thomas E. ernandez
E-mail: thomas.utcc@gmx.net

\begin{abstract}
The purpose of this paper is to assess the logistics performance of national trade corridors in Myanmar based on a theoretical portrayal of multimodal transport in logistics chains combined with the real-time operation of such chains. A cost-time-distance model was used as the core theoretical framework for the discussion. Empirical data related to cost, time and distance was obtained to evaluate national trade corridors in Myanmar. The study explored the performance of trade corridor in the pulses and beans sector from the largest sown and harvest areas to the main seaports in Myanmar. The pulses and beans sector was selected because the country is the $2^{\text {nd }}$ highest exporter in the world and would benefit from improved access to its national seaports. Under the cost-time-distance model used, it was observed that physical infrastructure, institutional environment as well as limited capability of local providers hindered the overall performance of the trade corridors under study.
\end{abstract}

Keywords Myanmar logistics, Trade corridors, South-East Asia, Least developed country, Country development

\section{Introduction}

Myanmar is the second largest country in Southeast Asia. It has a land area of approximately $676,578 \mathrm{~km}^{2}$ and is twice the size of Vietnam. Myanmar's 2020 population was estimated at 54,409,800 people according to United Nations data and its population density was estimated at 76 persons per $\mathrm{km}^{2}$. About $70 \%$ of the population lives in rural areas, according to the Myanmar population and housing census. Myanmar's economy is still very much dependent on agriculture, and the majority of the population in rural areas relies on subsistence agriculture for earning income and for food.

In spite of its favorable climate and rich natural resources, Myanmar is still one of the poorest nations in Southeast Asia. Prior to World War II in the late 1930s and early 1940s, Myanmar was a leading regional economy and a leading exporter of paddy/rice in the world. Myanmar's economy was greatly devastated during World War II. Much of the country's infrastructure was destroyed by the scorched-earth policies of the British when the Japanese invaded the country in 1942. The situation did not improve after the war because of the military dictatorship which made Myanmar a pariah on the world stage. The country re-opened in 2011 and a democratically elected government was put in place. Foreign assistance and investment started flowing into the country but growth was limited because of weak overall infrastructure in the country.

The Asian Development Bank (ADB), in its "Myanmar Transport Policy Note", released in 2016, estimated that the country needed some US\$ 60 billion in transport investment between 2016 and 2030. Highlighting the shortfall, the ADB stated that some twenty million people were without basic road access, while 60 percent of highways and most rail lines were in poor condition. Furthermore, even though the national paved highway network had increased by 35 percent between 2012 and 2016 , the number of vehicles in the country had doubled and travel within Yangon (the commercial capital) had become two to three times slower, with public transport operators losing some 35-65 percent of the market. To improve the situation, the democratic government launched a National Transport Master Plan in 2014, which identified 10 main corridors crucial to improving the country's transport network. The National Logistics Master Plan drafted in July 2016 and led by the Ministry of Transport and Communications identified the development of logistics corridors with assistance from JICA (2018).

According to an industry report on Myanmar's freight logistics (Mordor Intelligence, n.d.), road freight transportation is the main mode of transportation along with shipping and inland water transport. Road transport is the dominant mode of domestic transportation, helping connect rural areas and supporting regional and international trade. The road network in Myanmar is 
comparatively weak and underdeveloped with more than half of the road network being unpaved. Limited transport infrastructure coupled with the lowest motor vehicle penetration in Southeast Asia has resulted in high transportation costs and long travel times. This makes the trucking costs in the country higher when compared with other countries in the region.

Lack of focus in the road infrastructure and underinvestment remains a major hurdle for the road freight sector. In recent years, the government has realized the importance of logistics infrastructure and thus, has started to focus on the improvement of road infrastructure. This is expected to increase road usage for logistics activities in the future.

However, Myanmar logistics and transportation performance remains weak and lags behind that of other countries in the region (ADB 2016). Traders in Myanmar are struggling to compete with their export commodities in regional and international markets. Myanmar was ranked 137 out of 160 countries studied by the World Bank's Logistics Performance Index in 2018 (World Bank 2019).

Myanmar is the second largest global producer of beans and pulses (President's Office 2018). Pulses are defined as edible legumes including dry beans, peas and lentils (Ministry of Agriculture, Livestock and Irrigation 2017). The Ministry of Commerce (MoC) has an interest in improving performance of key domestic trade corridors related to the export of beans and pulses from Myanmar in order to enhance trade competitiveness. India is the biggest importer with more than 80 percent of Myanmar's annual 1.2 million tons of pulses and beans produce being exported to that country (Chern 2017). The original report was requested by the MOC to donor agencies and one of the authors was involved in the delivery of the work. The scope of work involved capacity building, knowledge transfer of the study methodology for replication purposes as well as policy recommendations.

The purpose of this paper is therefore to explain the methodology used to assess the logistics performance of national trade corridors in Myanmar. A cost-time-distance model was used as the core theoretical framework for the analysis based on the data collected from trade corridors.

The role of a trade corridor is to facilitate the production, consumption and distribution, or the supply chain, of goods and services. This means that goods must be produced and delivered to the market (or customer) in the right quantity, right condition, right quality, right place, right time and at the right price Trade, transportation, and economic development are by no means unrelated. Obviously, trade, whether within a country or overseas, is dependent largely upon the various transportation networks and corridors, on the sea, on inland waterways, across the land, or in the air. From an economic perspective, trade corridors provide two fundamental attributes for economic development: lower distribution costs and faster transit times.

A trade corridor is a set of routes between hub centers where maritime, fluvial, land and air transportation systems converge. The nature of convergence in trade corridors is twofold: First, there exist hub centers where transshipment functions are of prime importance and help allocate the capacity of the distribution system. This is the case of maritime, rail and air transportation corridors and also for some parts of fluvial transportation where in those conditions, hub centers tend to have a radial influence. Second, infrastructure limitations are the trade corridor's capacity constraints, like road transportation, and to some extent fluvial transportation.

\section{The case study: Myanmar}

Myanmar is classified as a Least Developed Country (LDC) by the UN (2018). It has a Logistics Performance Index (LPI) of 2.3 and ranks 137 of 160 in the world (World Bank 2019). The logistics requirements on the country are increasing due to the rapid growth (World Bank 2018). Myanmar's growth was inhibited since 1980 due to low investment, limited integration with global markets, dominance of state-owned enterprises in key productive sectors of the economy, and recurring periods of macroeconomic instability (Florento and Corpuz 2014). Since 2011, the country started a transition from military government to a democracy, and sanctions by the US and other countries were lifted starting from 2016. The lifting of sanctions has allowed foreign companies to engage in business with Myanmar companies and also to invest in the country. This led to economic growth, and growth in turn leads to an increase in cargo movements and logistics requirements for which the country was not yet prepared (Fernandez and Toe 2018).

Myanmar has a network of 157,000 km of paved roads, of which 3,003 km are part of the ASEAN Highways (AH) system as illustrated in Figure 1. The country also features $12,800 \mathrm{~km}$ of inland waterway and with $7,942.372 \mathrm{~km}$, the longest rail transport network in ASEAN (Htike 2014). According to the National Logistics Master Plan drafted by JICA in 2018, a number of limitations were observed related to the logistics infrastructure in the country.

- Trunk Road: The long-distance haulage of Myanmar is concentrated in the segment linking between Yangon and Mandalay. 
Although an expressway linking Yangon with Mandalay has been constructed, heavy-loaded vehicles are not allowed to use this expressway. The transport efficiency of heavy loaded vehicle for long-distance haulage is low in the country.

- Regional Roads: Trunk roads for regional connections are not adequately developed. Connections with neighboring countries were neglected until the country opened its door to the world in 2011. Road transport capacity cannot cater for future freight traffic. Bridges are structurally weak and cannot receive heavy-loaded vehicles. Many bridges will need to be reinforced or replaced by new bridges.

- Domestic Connectivity: Connectivity between rural and urban areas is weak and subject to natural disasters such as floods and landslides. The reinforcement of connectivity in both regional and domestic aspects is needed,

- International Port: At present, Yangon Port including the ports in the Thilawa Terminal Area is the only and largest commercial port in Myanmar.

- Transport and Logistics industry: The industry is fragmented and almost all are private small and medium size firms (SMEs).

Nonetheless, improvement can be seen with Myanmar implementing the Myanmar Automated Cargo Clearance Systems (MACCS) on 06 January 2017 (JICA 2017). MACCS is a computer system for customs clearance, which has greatly improved the efficiency and transparency at customs clearance. Myanmar is trying to improve its logistics performance on several levels, but the impact is not felt yet as its LPI score has not improved much. The LPI or the Logistics Performance Index is a benchmarking indicator developed by the World Bank to measure trade logistics connectivity. JICA (2014) also proposed upgrades to the AH Road Network in Myanmar.

In the 2018/2019 fiscal year, Myanmar exported a total of US\$ 17,060.415 million, the majority of which was US\$ 10,290.964 million of manufactured products, followed by agricultural products with a value of US\$ 3,725.698 million (Ministry of Commerce, n.d.). Within the agricultural sector, pulses are an important product. Production was 6 million tons in 2016 of which 1 million tons, valued at about US\$ 1 billion is exported each year. This is about 12 percent of total global exports of pulses by volume, and 19 percent by value, which makes Myanmar the second largest exporter of pulses in the world. It also means that pulses are Myanmar's largest exported agricultural produce (Ministry of Agriculture, Livestock and Irrigation 2017). In Myanmar, pulses and beans are usually grown during the winter period beginning in November. Growing periods take about three to four months from plantation to harvest, so that the crops are usually harvested from November to February or March (Aye et al. 2013).

There has been little academic research on the development of Myanmar Trade and Transport sector. This makes this paper important in terms of contributing to the logistics body knowledge related to Myanmar.

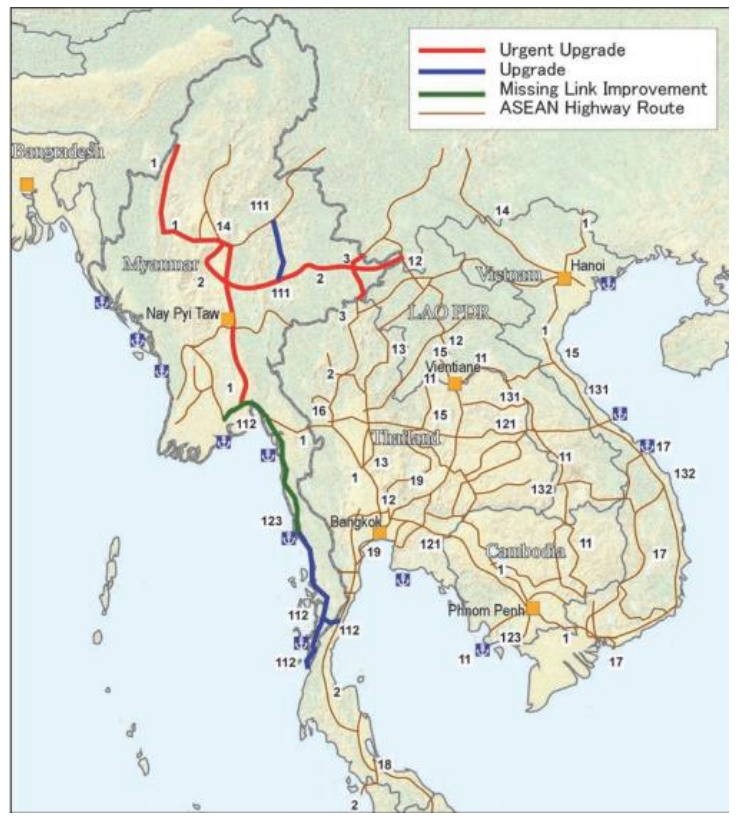

Figure 1. ASEAN Highway Road Network and proposed upgrades in Myanmar.

Source: JICA (2014). 


\section{Literature review: multimodal transport theory}

It has long been recognised that transport is a key activity within logistics (e.g. Christopher 2005; Cooper 1994; Hayuth 1987; Hayuth 1992; McKinnon 1989; Taplin 1982) and that, in turn, successful transport operations can be critical to supply chain efficiency both for inbound and outbound freight. For short-distance transport, especially internal land-based transport, solutions are usually clear-cut and simple; but over medium to long hauls modal combinations can be varied and complex (Beresford 1999). These combinations of transport modes for a multimodal transport can result in different delivery times and different cost (Beresford et al. 2011). The transport cost may sometimes be difficult to measure World Bank (2021), though.

The development related to the theory multimodal transport provision has received much less attention than its practical application. This is especially true of the portrayal of the economic theory, which underpins the concepts of, respectively, modal choice and modal combination. Several underlying principles determine the roles of the transport modes:

- The balance of fixed versus variable costs

- Modal characteristics, including networks, vehicles and regulatory regimes

- Economies of scale and the cube law

The advent and spread of containerization facilitated large-scale shipment of general cargo over long distances and rather than focusing on modal competition, emphasis was now placed on how modes could best combine to produce, least-cost, leastdistance or least-time solutions. Despite this revolutionary change in transport techniques in the field, the literature was lagging behind with the emphasis still on modal choice (McKinnon 1989) road-rail competition (Fowkes et al. 1989a, 1989b), intermodality (Hayuth 1987) and modal indifference (Baumol and Vinod 1970).

All methods of transport involved efforts (and hence implicitly cost) to provide and load the vehicle and, of course, to gain access to the relevant infrastructure. This start-up process can be envisaged as a vertical step in the curve with the height of the step being proportionate to the start-up cost. It is widely acknowledged that the bundle of costs enabling start-up is substantially greater for rail than for than for road transport but, conversely, provided the relevant load carrying units are well-utilized, there is a significant cost-saving per ton-km by using rail vis-à-vis road (Fowkes et al. 1989a, 1989b) over a certain distance. In any event, the road and rail operating cost curves can be envisaged as a start-point for a more inclusive model.

The first re-examination of the classic 'road versus rail approach' taken by Fowkes et al (1989a) was by Beresford and Dubey (1990). The focal point of their study was the development of 'Dry Ports' or Inland Container distribution hubs as an integral part of trade expansion and modal integration. Thus, the literature, hitherto mostly restricted to a road/rail debate, was extended to embrace sea and inland waterway transport as suggested in Figure 2.

The theory of multimodal transport is complex; it cannot be viewed as a simple extension of traditional bimodal models. It is proposed that distance, time and cost should be considered as secondary and, as such, they can be invoked as an overlay to the main model as illustrated in Figure 2. A generic form of the model, enabling the reader to dissect both the intermodal transfer components and the transport or movement elements, is now available on the UNESCAP website (https://www.Unescap .org/resources/timecost-distance-methodology). The model has now become a key tool for transport and logistics policy makers in the assessment of economic corridors.

The structure of the time/cost-distance model can be tested against real conditions in a range of circumstances; at the center of the model's logic is the relative operating costs and the fixed costs of necessary infrastructure provision for the respective transport modes. Multimodal transport systems give us the opportunity to examine the trade-offs and to present them numerically. Especially interesting is the way the model enables the trade-offs to be visualized. In this research, the cost/time distance model has been identified and used as the method of analyzing logistics costs, schedules and service attributes observed over a variety of routes in a wide range of operational circumstances. The multimodal transport cost model is well explained in Beresford (1999) with its theoretical foundation and a validating case study related to the movement of whisky from Scotland to Greece.

Looking more generally at global logistics management, key requirements are the delivery of the goods to the right place, at the right time and at the right price (Janelle and Beuthe 1997). The aim is to create a supply chain, which balances cost and customer satisfaction during the transportation process within a global market. According to the World Bank (2000) the cost of transport is the single largest element in bringing goods to market and this cost starts from the origin to the seaport to the final destination. For international movements, the search to reduce costs and improve customer service has resulted in the integration of not only the supply chain, but also activities in the supply chain, including transport, and the service providers themselves 

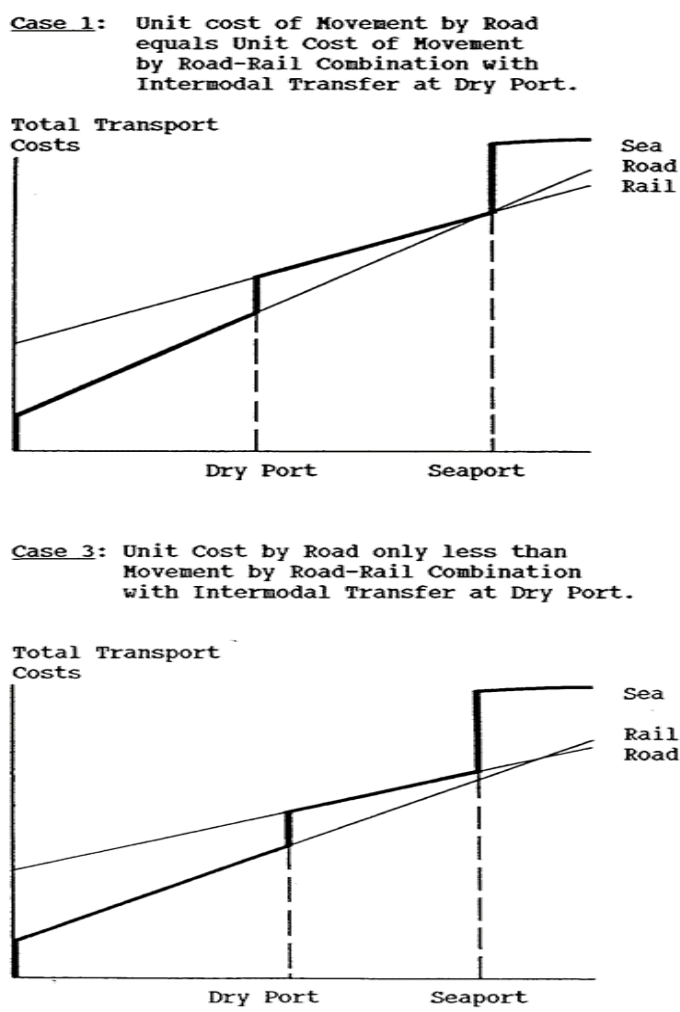
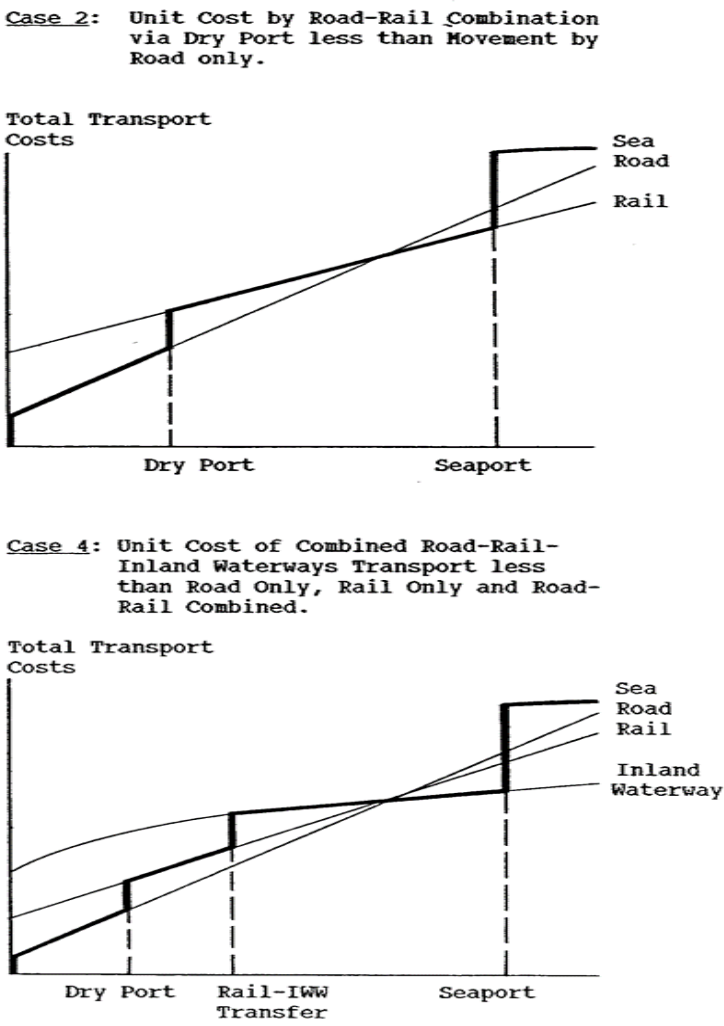

Figure 2. Combined transport modelling.

Source: Beresford and Dubey (1990).

\section{(Coyle 2003).}

Beresford and Dubey (1990) and Beresford (1999) describes how multimodal transport systems are conceptualized. As such both papers reflect that integrated door to door transport is not a seamless operation. There will be stops along the way when goods have to change transport modes or when tolls or borders have to be crossed. However, cost, time and distance data is needed to actually represent what is happening within a corridor.

According to Beresford et al (2021), this multimodal cost/time-distance model not only helps to clarify the main trade-offs in a range of logistics circumstances, but also helps the understanding of the complex interaction over time. The model itself is not static; during the course of its development, it has advanced from being a speculative portrayal of multimodal transport chains, to a thoroughly tested and widely used operations management tool with a range of applications. The model as presented in this paper is used first as an analytical tool for logistics operations. Second, it can inform transport and logistics operators regarding tactics for choosing, for example, least risk or maximum gain logistics solutions. Finally, results from the model enables policy makers to develop strategies especially in the field of logistics, which encourage growth, cooperation and development at a supra-regional level. The use of this model provided an initial baseline related to the performance of trade corridors in Myanmar. It must not be forgotten that before any improvement can be made, baseline assessment is the necessary precondition.

\section{Methodology}

This study uses a trade logistics cost and time methodology for corridor evaluation. The Cost/Time-Distance model applied in this study includes the main elements of cost, time, distance, transport mode and intermodal transfer. In this methodology, all cost that occur during the movement of goods are considered, including, among other charges, also terminal charges, customs clearance charges and any "tea money". "Tea money" is a local euphemism for small but regulator bribes, which is quite a normal practice in the region, as Banomyong and Beresford (2001) described. According to Transparency International (2020), Myanmar ranks quite low on the Corruption Perception Index (CPI), a yearly survey using several data points in each country. The CPI is a composite index which combines the findings of 13 surveys from independent institutions that are specialised in 
governance and business climate analysis. The institutions are not commissioned by Transparency International, they merely summarise them and assign scores, with a maximum of 100 . Then, each country is ranked against all other countries that were included in that particular year. Table 1 shows Myanmar's ranking in the years 2010 to 2020. For example, in the year 2017, Myanmar ranked 130 of a total of 180 countries surveyed.

The table shows that Myanmar's CPI improved after the end of the military regime in 2011 but did not really overcome the practice. Therefore, including this "tea money" gives a more realistic overview of logistics cost than just the transportation cost.

This study focused on trade corridors of four major export commodities in the pulses and beans sector, which are black gram or black matpe bean, green gram or green mung bean, pigeon peas and chickpeas. The logistics of these four major export pulses produce were analyzed from the largest sown and harvest areas in the country to the main seaports. All routes use Yangon port as the port of export, so the seafreight charges would not differ. The tables hereunder illustrate the data that needs to be collected to build the cost/time distance model. The sown/harvest areas as the points of origin, and the yield and production of four major export legumes crops as the volume were compiled from the Pulses section, the Agricultural Extension Division, Department of Agriculture (DoA), Ministry of Agriculture, Livestock and Irrigation, and the sown areas were confirmed with traders and exporters in Yangon. Table 2, 3, and 4 describe the data that needs to be collected.

In this study, the first step was to determine the Average Speed with Resting Time (ASRT) and the Average Speed Without Resting Time (ASWRT) for trucking from the respective origins to Yangon port, along with the cost per km in Myanmar Kyat (MMK), the local currency. At the time of the research, the exchange rate was about MMK 1,350 per US\$1.00.

In the next step, the percentage of transport and non-transport related time and cost were determined. Non-transport cost, and non-transport time includes reloading or terminal charges, which add to the total cost without contributing to the transport of the produce. The percentage of logistics cost of the Yangon price of the produce was then compared to the Free-on-Board (FOB) prices (based on selling prices) to understand the cost added for export.

The four designated routes are: 1) Kantbalu Township to the ports in Yangon, 2) Pale Township to the ports in Yangon, 3)

Table 1. Corruption perception index of Myanmar

\begin{tabular}{cccc}
\hline Year & CPI rank & Year & CPI rank \\
2020 & $137 / 180$ & 2014 & $156 / 175$ \\
2019 & $130 / 180$ & 2013 & $157 / 177$ \\
2018 & $132 / 180$ & 2012 & $172 / 176$ \\
2017 & $130 / 180$ & 2011 & $180 / 183$ \\
2016 & $136 / 176$ & 2010 & $176 / 178$ \\
2015 & $147 / 168$ & & \\
\hline
\end{tabular}

CPI, corruption perception index.

Source: Transparency International (2020).

Table 2. Trade data required

\begin{tabular}{ccccc}
\hline Export & Country of destination & Annual value (US\$) & Annual volume (ton) & Transport modes \\
Product A & & & \\
Product B & & & \\
Product C & & & \\
Product D & & & \\
\hline
\end{tabular}

Table 3. Assessing infrastructure

\begin{tabular}{|c|c|c|c|c|c|c|}
\hline Trade corridor & Surface type & $\begin{array}{l}\text { Road } \\
\text { class }\end{array}$ & No. of lanes & $\begin{array}{l}\text { Average speed } \\
\text { (ASRT) }\end{array}$ & $\begin{array}{l}\text { Average speed } \\
\quad \text { (ASWT) }\end{array}$ & Fees collected \\
\hline \multicolumn{7}{|l|}{$\begin{array}{l}\text { Origin \& destination } \\
\text { (with road name or no.) }\end{array}$} \\
\hline \multicolumn{7}{|l|}{$\begin{array}{l}\text { Origin \& destination } \\
\text { (with railway line) }\end{array}$} \\
\hline $\begin{array}{l}\text { Origin \& destination } \\
\text { (with river route) }\end{array}$ & & & & & & \\
\hline
\end{tabular}


Table 4. Sample data table

\begin{tabular}{|c|c|c|c|c|c|c|c|}
\hline Leg & Mode & $\begin{array}{l}\text { Distance } \\
(\mathrm{km})\end{array}$ & $\begin{array}{c}\text { Cum. } \\
\text { distance }(\mathrm{km})\end{array}$ & $\begin{array}{l}\text { Cost } \\
\text { (US\$) }\end{array}$ & $\begin{array}{l}\text { Cum. cost } \\
\text { (US\$) }\end{array}$ & $\begin{array}{l}\text { Transit } \\
\text { time }(\mathrm{h})\end{array}$ & $\begin{array}{l}\text { Cum. time } \\
\text { (hours) }\end{array}$ \\
\hline A to $B$ & Road & 100 & 100 & 50 & 50 & 4 & 4 \\
\hline Border crossing & - & - & & 100 & 150 & 6 & 10 \\
\hline $\mathrm{B}$ to $\mathrm{C}$ & Road & 70 & 170 & 30 & 180 & 3 & 13 \\
\hline Intermodal transfer & - & - & & 40 & 220 & 3 & 16 \\
\hline C to $\mathrm{D}$ & Rail & 200 & 370 & 60 & 280 & 18 & 34 \\
\hline Port & - & - & & 20 & 300 & 6 & 40 \\
\hline $\mathrm{D}$ to $\mathrm{E}$ & Sea & 800 & 1,170 & 300 & 600 & 72 & 112 \\
\hline Total & & 1,170 & & 600 & & 112 & \\
\hline
\end{tabular}

Source: UNESCAP (2003).

Kyauktagar Township to the ports in Yangon, and 4) Kawa Township to the ports in Yangon. The designated trading routes are starting from sown areas of four major export legumes crops to the ports in Yangon as shown in Figure 3.

In order to obtain data that reflects the current situation in Myanmar, a number of respondents were identified. These respondents were from related trade associations, exporters, traders, small traders from sown areas of the four major export legumes crops, highway-truck and container-truck drivers, customs and shipping agents, government staff as shown in Table 5. These respondents were able to describe the various logistics issues affecting the performance of the trade corridors from the sown areas to the port of loading. Key informant discussions were conducted in Yangon and the study team made numerous field visits at various townships to collect necessary data and information for the analysis of logistics issues affecting the performance of the trade corridors under study.

Other stakeholders such as staff of Shipping Agency Department (SAD), Inland Container Depot, and the Ministry of Construction were also interviewed to get necessary information and data such as terminal handling charges, Inland Container
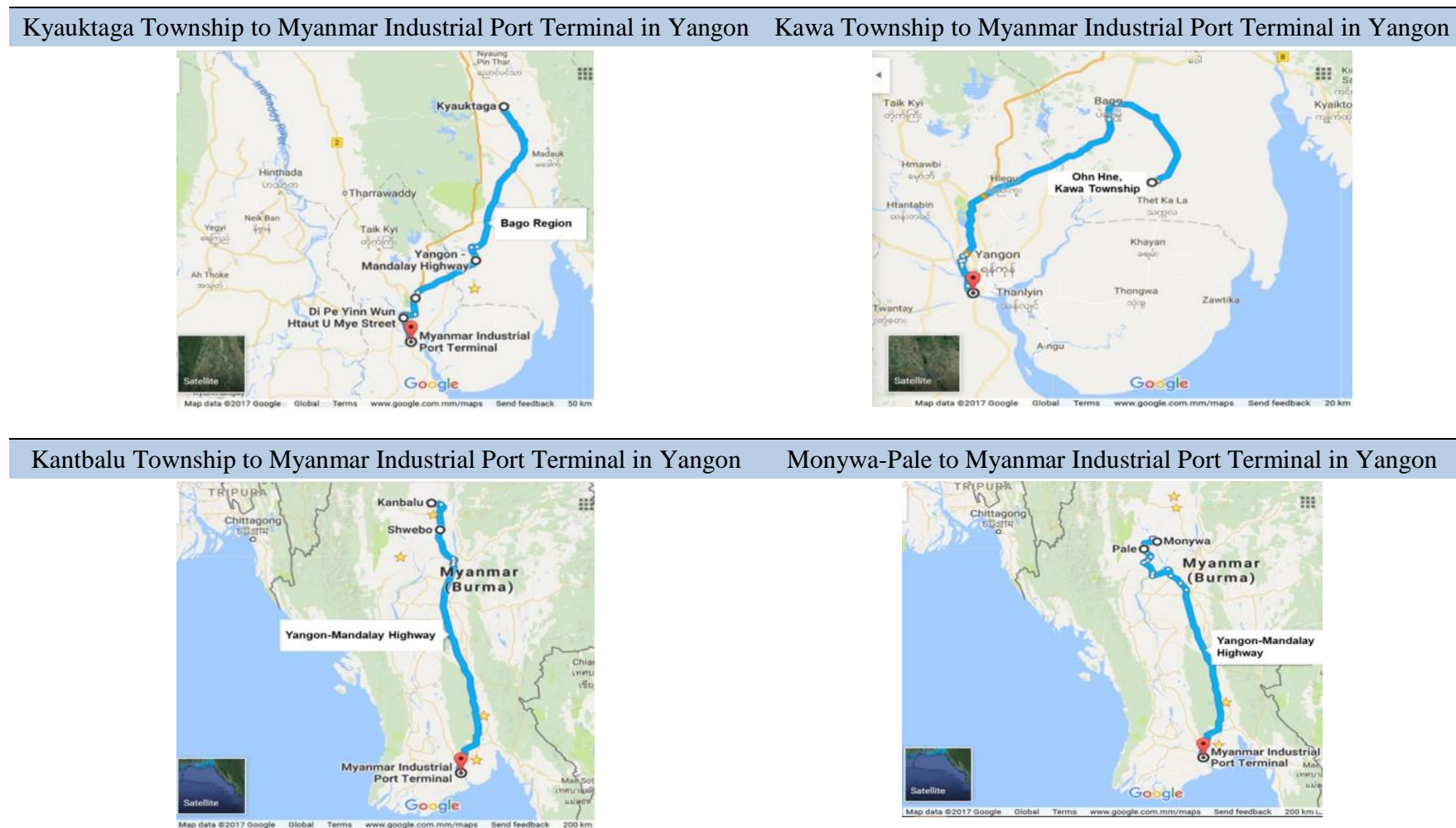

Figure 3. Main corridors for key pulses and beans export.

Source: Google Maps (2017). 
Table 5. List of stakeholders interviewed

\begin{tabular}{|c|c|c|}
\hline Location & Stakeholder & Number \\
\hline Yangon & Myanmar Pulses, Beans and Sesame Seeds Merchants Association (MPBSMA) & 12 \\
\hline Yangon & Myanmar Highway Freight Transportation Services Association (MHFTSA) & 5 \\
\hline Yangon & $\begin{array}{l}\text { Chainman, Vice-Chairman and members of Myanmar Container Truck Association } \\
\text { (MCTA) }\end{array}$ & 12 \\
\hline Yangon & Myanmar International Freight Forwarder Association (MIFFA) & 8 \\
\hline $\begin{array}{l}\text { Zigon and Kanbalu Towns, Shwe } \\
\text { Bo City }\end{array}$ & 18 Traders and 4 truck drivers, and 3 staff officers of Department of Agriculture & 25 \\
\hline $\begin{array}{l}\text { Mintaingpin and Kandaung villages, } \\
\text { Pale Township, and Monywa }\end{array}$ & 10 Traders and 13 truck drivers, and 3 staff officers of Department of Agriculture & 26 \\
\hline $\begin{array}{l}\text { Monywa Commodity Exchange Centre, } \\
\text { and Brokerage Houses }\end{array}$ & $\begin{array}{l}5 \text { Traders in Monywa and nearby towns, Chairman and members of Sagaing Region } \\
\text { Chambers of Commerce and Industry }\end{array}$ & 6 \\
\hline $\begin{array}{l}\text { Mandalay Commodity Exchange Centre } \\
\text { (Bone Ka Hatin Association) and Swel } \\
\text { Taw Highway Station }\end{array}$ & $\begin{array}{l}\text { Traders in Mandalay and Vice President, and Joint Secretary General (Mandalay } \\
\text { Region Chamber of Commerce and Industry, MRCCI) and Vice President and } \\
\text { members of Highway Freight Transportation Services Association (HFTSA) }\end{array}$ & 10 \\
\hline Kyauktaga Town and Khin To Village & $\begin{array}{l}3 \text { Traders in Kyauktaga and Vice Chairman, Bago Region Chamber of Commerce } \\
\text { and Industry (BRCCI) }\end{array}$ & 4 \\
\hline Ohn Hne, Kawa Township & 5 Traders and 3 truck drivers, and 3 staff officers of DoA & 11 \\
\hline $\begin{array}{l}\text { Warehouses in Shwe Pyi Thar } \\
\text { Industrial Zone (4) }\end{array}$ & 4 warehouses officers, 2 Highway-truck and container-truck drivers & 6 \\
\hline $\begin{array}{l}\text { Warehouses in Shwe Pyi Thar and } \\
\text { Hlaing Thar Yar Industrial Zones }\end{array}$ & 6 warehouse officers, 2 Highway-truck and container-truck drivers & 8 \\
\hline $\begin{array}{l}\text { Company Offices and Plant } \\
\text { Protection Department in Yangon }\end{array}$ & $\begin{array}{l}5 \text { Export \& Import companies and } 5 \text { Customs Services \& Port Clearance Agency; } 2 \\
\text { Shipping lines }\end{array}$ & 12 \\
\hline $\begin{array}{l}\text { Inland Container Depot (ICD) and } \\
\text { Shipping Agency Department (SAD) }\end{array}$ & ICD operator & 2 \\
\hline
\end{tabular}

DoA, department of agriculture.

Depot (ICD) operation, road maps and references for distances between Toll Gates along the Yangon-Mandalay Highway of the designated routes. The study team made follow-up clarifications on the collected data and information with different stakeholders as necessary. Transportation costs and time spent on each leg are mainly provided by local traders and collectors in villages and towns, and big merchants in the cities, Highway-truck and container-truck owners and drivers.

\section{Findings}

This section will present the obtained data from the stakeholders. The objective is to present the baseline performance of the 4 trade corridors under study. The corridors are assessed based on three main dimensions, as discussed in the literature, which are cost, time and distance. Table 6 and 7 provide basic information related to speed, cost per km for specific commodities.

The average speed along the trade corridor described in Table 6 may not be quite high but it is already quite good considering the state of the road infrastructure in the country. The key issue in terms of transit speed is not really from the sown area to the industrial zones but from the industrial zones to the ports in Yangon. Access to ports is congested and this is reflected in the average speed taken to access the ports in Yangon and the price per $\mathrm{km}$.

Table 7 shows depending on the commodity moved, cost and time efficiency of driving from Shwe Bo to Yangon is the best

Table 6. Average speed per $\mathrm{km}$ and cost per $\mathrm{km}$ of the designated route for black gram and green gram

\begin{tabular}{ccccccc} 
Major legs of the designated routes & \multicolumn{3}{c}{ Kantbalu, Shwe Bo-Yangon } & \multicolumn{3}{c}{ Pale, Monywa-Yangon } \\
\cline { 2 - 7 } & $\begin{array}{c}\text { ASRT } \\
(\mathrm{km} / \mathrm{h})\end{array}$ & $\begin{array}{c}\text { ASWRT } \\
(\mathrm{km} / \mathrm{h})\end{array}$ & $\begin{array}{c}\mathrm{C} \\
(\mathrm{MMK} / \mathrm{km})\end{array}$ & $\begin{array}{c}\text { ASRT } \\
(\mathrm{km} / \mathrm{h})\end{array}$ & $\begin{array}{c}\text { ASWRT } \\
(\mathrm{km} / \mathrm{h})\end{array}$ & $\begin{array}{c}\mathrm{C} \\
(\mathrm{MMK} / \mathrm{km})\end{array}$ \\
$\begin{array}{c}\text { From Kyauktaga/Ohne Hne, Kawa to Yangon } \\
\text { From I-SPT to the ports }\end{array}$ & 30 & 38 & 1,345 & 29 & 40 & 1,554 \\
\hline
\end{tabular}

ASRT, average speed with resting time; ASWRT, average speed without resting time; Cost per km=C (MMK/km); I-SPT, the industrial zones in Shwe Pyi Thar in Yangon; MMK, Myanmar Kyat. 
Table 7. Average speed per km and cost per km of the designated route for Pigeon Peas and Chickpeas

\begin{tabular}{|c|c|c|c|c|c|c|}
\hline \multirow[b]{2}{*}{ Major legs of the designated routes } & \multicolumn{3}{|c|}{ Kantbalu, Shwe Bo-Yangon } & \multicolumn{3}{|c|}{ Pale, Monywa-Yangon } \\
\hline & $\begin{array}{l}\text { ASRT } \\
(\mathrm{km} / \mathrm{h})\end{array}$ & $\begin{array}{l}\text { ASWRT } \\
(\mathrm{km} / \mathrm{h})\end{array}$ & $\begin{array}{c}\mathrm{C} \\
(\mathrm{MMK} / \mathrm{km})\end{array}$ & $\begin{array}{l}\text { ASRT } \\
(\mathrm{km} / \mathrm{h})\end{array}$ & $\begin{array}{l}\text { ASWRT } \\
(\mathrm{km} / \mathrm{h})\end{array}$ & $\begin{array}{c}\mathrm{C} \\
(\mathrm{MMK} / \mathrm{km})\end{array}$ \\
\hline $\begin{array}{l}\text { From Kantbalu to Shwe Bo/ Mintaingpin, } \\
\text { Pale to Monywa }\end{array}$ & 27 & 30 & 1,418 & 28 & 30 & 1,856 \\
\hline From Shwe Bo/Monywa to I-SPT & 35 & 45 & 1,259 & 36 & 47 & 1,147 \\
\hline From I-SPT to the ports & 9 & 10 & 8,174 & 9 & 10 & 9,175 \\
\hline
\end{tabular}

ASRT, average speed with resting time; ASWRT, average speed without resting time; Cost per $\mathrm{km}=\mathrm{C}(\mathrm{MMK} / \mathrm{km})$; I-SPT, the industrial zones in Shwe Pyi Thar in Yangon; MMK, Myanmar Kyat.

Source: The Authors.

among different legs of this designated route, followed by that of driving from Kantbalu to Shwe Bo. The average cost per km in Yangon part is about seven times more than that of the transportation from Shwe Bo to Yangon. The average driving speed in Yangon is significantly lower than from the origins of the produce as this is due to congestion combined with truck bans for seaport access. The low average speed is due to the state of the roads combined with congestion in Yangon. Overtaking is difficult as most of the roads are single lane. Average speed is not higher than $35 \mathrm{~km}$ per hours but in the Yangon area the average speed is at around $9 \mathrm{~km}$ per hours. Since there are no other modes available to link with Yangon port, shippers have to take into account the low speed of delivery when planning their delivery.

Figure 4 provides a graphical representation of the activities occurring within the Kantbalu to ports in Yangon trade corridor. As expected the longer the distance, the higher time and cost will be within the trade corridor. The details obtained from the model highlights the number of stops along the corridor and that the logistics of the commodities is not seamless as there is quite some time taken for tolls along the corridor. The study team collected cost and time data along the trade corridor, from origin to final destination at Yangon port. At each location where the truck stops, the time and the cost were noted into a table. The data in the table, as described in Table 3, is then used to plot a graph with the time and cost data represented in the vertical axis and the distance data in the horizontal axis.

Figure 4 is the representation of a door-to-door operation from the sown area to Yangon port. The figure is developed based on the conceptual model of Beresford and Dubey (1990) and Beresford (1999). The figure reflects the obtained cost, time and distance data with all the "stop" or "activities" incurred from origin to destination.

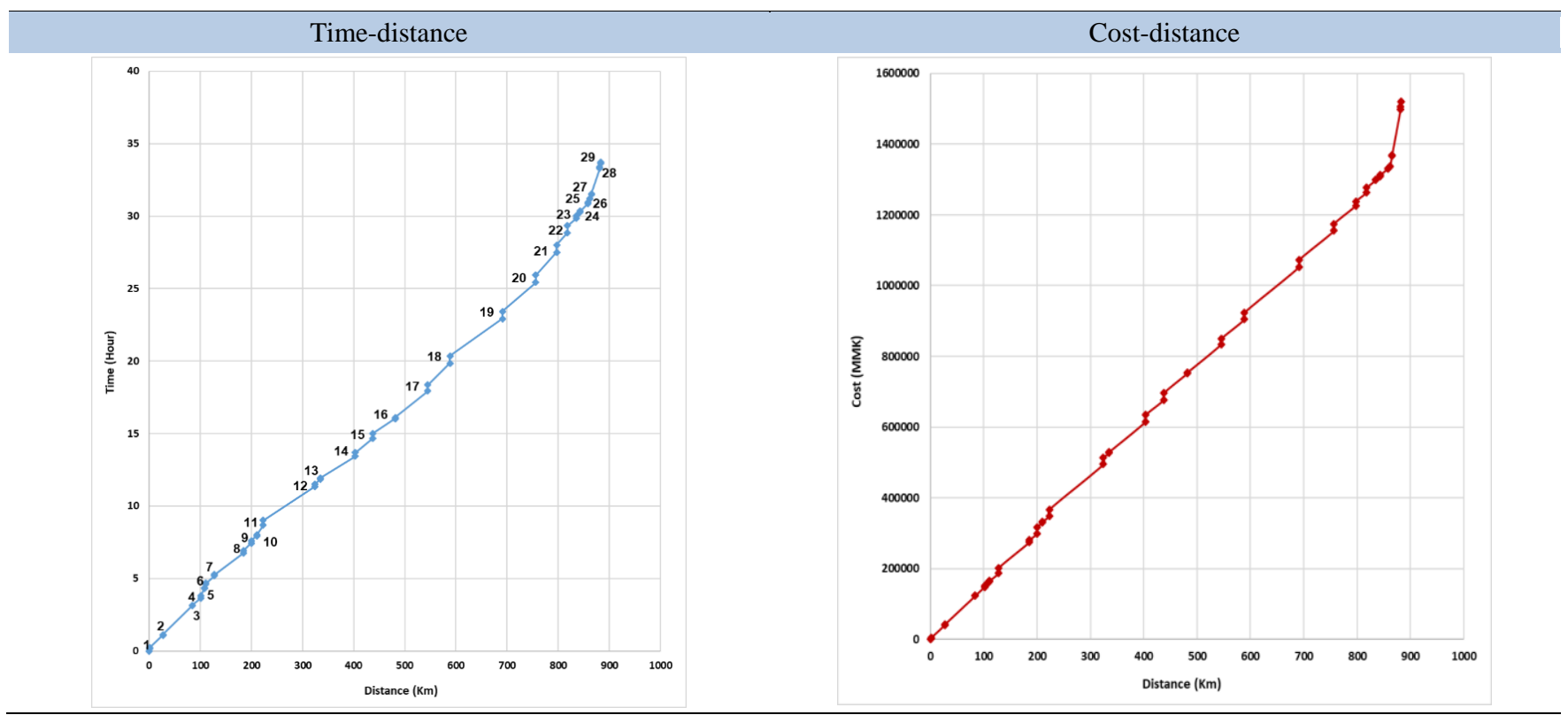

Figure 4. Trade Corridor-Kantbalu Township to ports in Yangon.

Source: The Authors. 
The time-distance model illustrates that there are in total 29 "stops" or "activities" that occur within the trade corridor. The first activity is the commodity moving from the sown area while the last activity is the commodity being unloaded at Yangon port. There are a number of vertical steps, this means that the vehicle transporting the commodity is not moving because of congestion or queuing to pay tolls along the corridor. Even though people assume that movement along trade corridors in Myanmar is seamless, the reality is much different. It is observed that the first and last mile are the corridor legs with higher steepness of the model curve. This means that it takes longer by distance than in the middle of the trade corridor. The reason is that in the middle of the trade corridor, there are less stops apart and when these stops occur, it is because the truck has to wait at the tollgate.

The cost-distance model also reflects what was observed in the time-distance model. Each time the vehicle has to stop there is a charge or fee that needs to be paid. This is represented by the square along the cost curve in the cost-distance model. There are 37 "stops" or "activities" on the cost model thus meaning that along the trade corridors, payment needs to be made 37 times before the goods can arrive at final destination for unloading at ports in Yangon. The last mile is the most expensive leg by the $\mathrm{km}$ but on average the cost curve is quite steep. This means that the cost per $\mathrm{km}$ is higher when compared to the steepness of the time curve.

Figure 4 provides an example how the collected data can be illustrated with the time/cost model. The time/cost model was used for the four main trade corridors to highlight locations where vehicles had to stop and the various fees being charged along the various trade corridors. This graphical representation provides policy makers with issues to be discussed and resolved.

Tables 8 and 9 describe the non-transport related cost and time. Even though the ratio of non-transport related cost is not high when compared to non-transport related time but both reflect the challenges of vehicle movement along trade corridors in Myanmar. Table 8 shows that on the Kyautaga-Yangon route, $77 \%$ of the transport time were actual driving times, while 23\% were non-driving times. Between Ohn Hue and Yangon, there were even $26 \%$ of non-driving times.

In Table 9, it is interesting to note that the leg between Shwe Bo/Monywa to I-SPT is the leg that has the highest ratio of nontransport related time and cost while the first and last mile has ratios of less than $10 \%$ for non-transport related cost and time.

In the selected trade corridors for pigeon peas, chickpeas, black gram and green mung beans, the overall logistics costs are not major issues as the estimates of domestic logistics cost are between 4 to 8 percent while export logistics cost (FOB cost)

Table 8. Percentage of transport and non-transport for black gram \& green gram

\begin{tabular}{l} 
Table 8. Percentage of transport and non-transport for black gram \& green gram \\
\multicolumn{1}{c}{ Major legs } \\
\cline { 2 - 4 }
\end{tabular}

T, transport; NT, non-transport related; I-SPT, the industrial zones in Shwe Pyi Thar in Yangon.

Table 9. Percentage of transport and non-transport for pigeon peas and chickpeas

\begin{tabular}{|c|c|c|c|c|}
\hline \multirow{2}{*}{ Major Legs of the Designated routes } & \multicolumn{2}{|c|}{ Kantbalu, Shwe Bo-Yangon } & \multicolumn{2}{|c|}{ Pale, Monywa-Yangon } \\
\hline & $\mathrm{T}(\%)$ & NT $(\%)$ & $\mathrm{T}(\%)$ & NT $(\%)$ \\
\hline \multicolumn{5}{|c|}{ From Kantbalu to Shwe Bo/Mintaingpin, Pale to Monywa } \\
\hline Time & 91 & 9 & 92 & 8 \\
\hline Cost & 95 & 5 & 96 & 4 \\
\hline \multicolumn{5}{|l|}{ From Shwe Bo/Monywa to I-SPT } \\
\hline Time & 78 & 22 & 76 & 24 \\
\hline Cost & 76 & 24 & 73 & 27 \\
\hline \multicolumn{5}{|l|}{ From I-SPT to the ports } \\
\hline Time & 91 & 9 & 91 & 9 \\
\hline Cost & 94 & 6 & 94 & 6 \\
\hline
\end{tabular}

T, transport; NT, non-transport related; I-SPT, the industrial zones in Shwe Pyi Thar in Yangon. 
Table 10. Logistics cost/sales of the 4 commodities

\begin{tabular}{ccc}
\hline Type of peas & Logistics cost/Yangon price $(\%)$ & Logistics cost/FOB price $(\%)$ \\
Pigeon Peas & 8 & 10 \\
Chickpeas & 5 & 6 \\
Black Gram & 4 & 5 \\
Green Gram & 4 & 4 \\
\hline
\end{tabular}

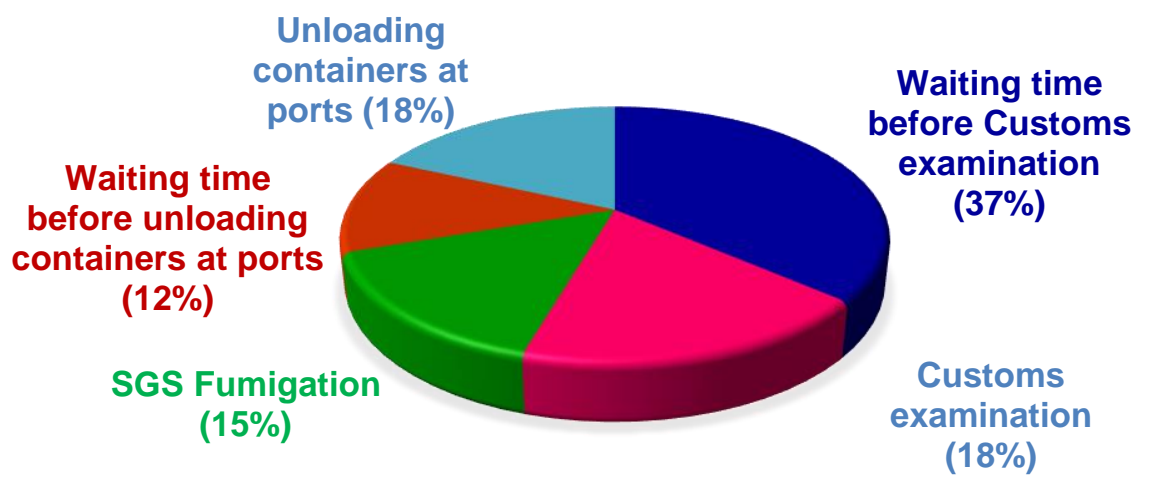

Figure 5. Time taken at port for export process.

Source: The Authors.

are between 4 to 10 percent (Table 10). However, it is interesting to see that there is a difference of $2 \%$ for pigeon peas logistics cost. This means that even though the distance is not far from the industrial zones to ports in Yangon but the cost involved in the delivery and loading at the port is quite significant. Only the Green Gram commodity is not subject to an increase in cost for export purposes under FOB.

\subsection{Port delivery process}

Container trucks depart at 8-9 pm from the Ahlone Township Cargo Cars Park or neighboring ICDs and arrive at 10-12 pm at the warehouses in the industrial zones. Containers are stuffed the following morning and driven back to the various ports in Yangon for Customs examinations in the evening. Shipping agents report to Customs when container trucks arrive at port container yard through the MACCS, and Customs will issue approval for shipment after containers are sealed by Customs. The process at the ports takes about three to five hours from $11 \mathrm{pm}$ to 2-3 am the following day. This means that it takes more than 24 hours after arrival to Yangon for the commodities to be processed and are ready for export.

The most challenging issues observed in the Yangon region are: (1) the impact of the Yangon Regional Government restriction that forbids truck operations in the city from 6 am to $8 \mathrm{pm}$. (2) the study identified time taken related to procedures at ports such as Customs examinations and other logistics matters. About $37 \%$ of the total time spent at the ports is waiting time before Customs examination. The waiting time before unloading containers is about $12 \%$ as illustrated in Figure 5. Figure 5, highlights time related issues at ports in Yangon. (3) There are also issues associated with the loading and unloading of containers at ICDs. These challenges to the logistics system in Yangon increase cost and reduce average speed per km.

\section{Conclusions and Recommendations}

This study on the performance of national trade corridors for four major export produce such as green mung gram, black gram, pigeon peas, and chickpeas provides valuable insights to understand logistics issues in the designated corridors. The model employed in this study consists of three main dimensions i.e. cost, time and distance. Under the cost-time-distance model used, it was observed that physical infrastructure, institutional environment as well as capability of local providers hindered the overall performance of the trade corridors under study.

The physical infrastructure had a direct impact on the average speed of vehicles and is reflected in the overall low speed but in sections with improved road infrastructure, the average speed is higher. The ratio of transport time and cost referring to the 
actual driving time without resting and waiting time are lower while that of the non-transport related time and cost are higher in the designated routes from the regions to Yangon compared to the results for the leg in the Yangon part. This means that several hours can be reduced if all toll gates are removed along the Yangon-Mandalay Highway.

More specifically, the findings of the study suggest that the average cost per km between the warehouses in Shwe Pyi Thar industrial zones and the ports is about 6 to 8 times higher than that of the transportation from Shwe Bo, Monywa and Bago regions to Yangon. Therefore, the findings of the study indicate that there are higher levels of inefficiencies in logistics and transportation in the Yangon part of the selected national trade corridors.

The inefficiencies found around the Yangon area are derived from limited infrastructure but mostly from a non-enabling institutional framework that restricts movement of movement of freight during day time. It is understandable that Yangon would like to reduce congestion but this should not be at the expenses of logistics. The role of logistics service providers has not been highlighted enough. Truckers would like to have better utilization rates of their vehicles but because of reduced speed and restrictions in Yangon, the service price becomes much higher than for providing services to the rest of the country.

The findings of the study show that there are many logistics inefficiencies between the industrial zones to the seaports in Yangon compared to the other legs along selected national trade corridors. Hence, a comprehensive policy is needed to improve capability of national trade corridors. These policies could be led by the $\mathrm{MoC}$, but not all issues fall under the jurisdiction of the $\mathrm{MoC}$ so inter-governmental coordination is crucial. If improvement policies are put in place, Myanmar's agricultural sector will become more competitive.

In February 2021, the military came back to power with a coup d'etat. This is a serious threat to improvement in the country's logistics system and if nothing is done to improve trade corridors in the country, the trade competitiveness of Myanmar will further deteriorate.

\section{Acknowledgements}

The authors would like to express their thanks to Ms Lwin Lwin Aung, Independent Consultant to the Ministry of Commerce, Myanmar, for her invaluable help in supervising and translating the data in this manuscript. This research would not have been possible without her. Further thanks are given to Thin Thin Kyaw, Khin Hsu Hlaing, Thet Naing Soe, Phone Myint Naing and Kyaw Si Thu, Gazetted Officers of Ministry of Commerce, Myanmar, for their kind support during the data collection.

\section{References}

ADB [Asian Development Bank], 2016. Myanmar Transport Sector Policy Note: Summary for Decision Makers. Publication Stock No. ARM168052-2. ADB, Manila, Philippines.

Aye, P. S., Htun, H. W., Myat, T. P., 2013. Myanmar's beans and pulses trade: Risks and prospects. Thura Swiss, Yangon, Myanmar.

Banomyong, R., Beresford, A. K. C., 2001. Multimodal transport: The case of Laotian garment exporters, International Journal of Physical Distribution \& Logistics Management 31, 663-685.

Baumol, W. J., Vinod, H. D., 1970. An inventory-theoretic model of freight transport demand. Management Science 16, 413421.

Beresford, A. K. C., 1999. Modelling freight transport costs: A case study of the UK - Greece corridor. International Journal of Logistics: Research and Applications 2, 229-246.

Beresford, A. K. C., Banomyong, R., Pettit, S., 2021. A critical review of a holistic model used for assessing multimodal transport systems. Logistics 5, 11.

Beresford, A. K. C., Dubey, R. C., 1990. Handbook on the management and operation of dry ports. United Nations Conference on Trade and Development, Geneva, Switzerland.

Beresford, A., Pettit, S., Liu, L., 2011. Multimodal supply chains: Iron ore from Australia to China. Supply Chain Management $16,32-42$.

Billen, D., 2016. For whom the road tolls: Funding highways in Myanmar. Myanmar times. Available at: https://www. mmtimes.com/opinion/21438-for-whom-the-road-tolls-funding-highways-in-myanmar.html

Chern, K. W., 2017. Expanding trade with India. Myanmar Times. Available at: https://www.mmtimes.com/news/expandingtrade-india.html

Christopher, M., 2005. Logistics and Supply Chain Management: Creating Value-Adding Networks. Pearson Education, 
London, UK.

Cooper, J., 1994. Logistics and Distribution Planning: Strategies for Management. Kogan Page, London, UK.

Coyle, J. J., Bardi, E. J., Langley, C. J. Y., 2003. The Management of Business Logistics: A Management Perspective, Thomson, Mason, Oh.

Google Maps. 2017. Myanmar Industrial Port. Available at https://www.google.com/maps/place/Myanmar+Industrial+Port

Fernandez, T. E., Toe, S. P. 2018. Logistics situation in Myanmar. Proceedings of the 10th International Conference on Logistics and Transport, Okinawa, Japan.

Florento, H., Corpuz, M. I., 2014. Myanmar: The key link between South Asia and Southeast Asia. ADBI Working Paper No. 506.

Fowkes, A. S., Nash, C. A., Tweddle, G., 1989a. Valuing the attributes of freight transport quality: Result of the stated preference survey. Institute of Transport Studies, University of Leeds, Working Paper No. 276.

Fowkes, A. S., Nash, C. A., Tweddle, G., 1989b. In what circumstances are intermodal systems competitive?. Institute of Transport Studies, University of Leeds, Working Paper No. 286.

Hamanaka, S., Tafgar, A., Ico, R., 2015. Constructing a bias-free trade governance indicator: Revealing the biases of existing survey indicators. ADB Economics Working Paper No. 454.

Hayuth, Y., 1987. Intermodality: Concept and Practice - Structural Changes in the Ocean Freight Transport Industry. Lloyd's of London Press, Colchester, UK.

Hayuth, Y., 1992. Multimodal freight transport. In: Hoyle, B. S., Knowles, R. D. (eds), Modern Transport Geography. Belhaven Press, London, UK.

Hitke, H., 2014. Status and future plan for national logistics master plan. Available at: https://www.unescap.org/sites/ default/files/Myanmar\%20-\%20Logistics.pdf

Janelle, D. G., Beuthe, M., 1997. Globalization and research issues in transportation. Journal of Transport Geography 5, 199206.

JICA [Japan International Cooperation Agency], 2014. The Survey Program for the National Transport Development Plan in the Republic of the Union of Myanmar. JICA, Tokyo, Japan.

JICA, 2017. Opening Ceremony of Myanmar Automated Cargo Clearance System (MACCS). Available at: https://www. jica.go.jp/myanmar/english/office/topics/press170106.html

JICA, 2018. Data Collection Survey on National Logistics in the Republic of the Union of Myanmar. JICA, Tokyo, Japan.

McKinnon, A. C., 1989. Choice of transport mode. In: Physical Distribution Systems. Routledge, London, UK.

Ministry of Agriculture, Livestock and Irrigation, 2017. Myanmar pulses sector development strategy. Available at: http:// extwprlegs1.fao.org/docs/pdf/mya190978.pdf

Ministry of Commerce. n.d. Trade situation of Myanmar in 2011-2012 fical year to 2020-2021 fical year (January Monthly). Available at: https://www.commerce.gov.mm/en/content/\%E1\%80\%95\%E1\%80\%B6\%E1\%80\%AF\%E1\%80\%AF\%E1\% 80\%99\%E1\%80\%BD\%E1\%80\%94\%E1\%80\%B9-\%E1\%80\%94\%E1\%80\%9A\%E1\%80\%B9\%E1\%80\%85\%E1\%80\%9 5\%E1\%80\%B9-\%E1\%80\%80\%E1\%80\%AF\%E1\%80\%AF\%E1\%80\%94\%E1\%80\%B9\%E1\%80\%95\%E1\%80\%85\%E1 $\% 81 \%$ A5\%E1\%80\%8A\%E1\%80\%B9\%E1\%80\%B8\%E1\%80\%A1\%E1\%80\%9C\%E1\%80\%AD \%E1\%80\%AF\%E1\%80 $\%$ AF\% $\% 1 \% 80 \% 80 \% \mathrm{E} 1 \% 80 \% \mathrm{~B} 9$

Mordor Intelligence. n.d. Myanmar freight and logistics market - growth, trends, covid-19 impact, and forecasts (2021-2026). Available at: https://www.mordorintelligence.com/industry-reports/myanmar-freight-logistics-market-study

Palvia, S. C. J., Sharma, S. S., 2018. E-government and e-governance: Definitions/domain framework and status around the world. Computer Society of India, Mumbai, India.

President's Office. 2018. Beans, pulses farmers urged to grow marketable crops to cope with market change. The Republic of the Union of Myanmar. Available at: http://www.president-office.gov.mm/en/?q=briefing-room/news/2018/08/18/id-8944

Taplin, J. H. E., 1982. Inferring ordinary elasticities from choice of mode-split elasticities. Journal of Transport Economics and Policy 16, 55-63.

Transparency International, 2020. Corruption perception index. Available at: https:/www.transparency.org/en/cpi/2020/index/ myanmar\#

UN [United Nations], 2018. Least developed country category: Myanmar profile. Available at: https://www.un.org/ development/desa/dpad/least-developed-country-category-myanmar.html

UNESCAP, 2003. Transit Transport Issues in Landlocked and Transit Developing Countries, United Nations, New York 2003, ST/ESCAP/2270. Avaialble at: https://www.unescap.org/sites/default/d8files/pub_2270_fulltext.pdf 
World Bank, 2018. Myanmar. Available at: https://data.worldbank.org/country/myanmar

World Bank, 2019. Country score card: Myanmar 2018. Available at: https://pi.worldbank.org/international/scorecard/radar/ 254/C/MMR/2018\#chartarea

World Bank, 2000. Global logistics. Available at: https://www.worldbank.org/en/news/feature/2008/06/16/landlocked-countrieshigher-transport-costs-delays-less-trade

World Bank, 2021. International transport costs: Why and how to measure them? Available at: https://blogs.worldbank.org/ transport/international-transport-costs-why-and-how-measure-them 